\title{
Estrogen inhibition of norepinephrine responsiveness is initiated at the plasma membrane of GnRH-producing GT1-7 cells
}

\author{
Araceli Morales*, Miriam Gonzalez*, Raquel Marin, Mario Diaz ${ }^{1}$ and Rafael Alonso \\ Laboratory of Cellular Neurobiology, Department of Physiology and ${ }^{1}$ Laboratory of Animal Physiology, Department of Animal Biology, Institute of Biomedical \\ Technologies, University of La Laguna, La Laguna, Spain \\ (Requests for offprints should be addressed to A Morales; Email: mamoral@ull.es) \\ *(A Morales and M Gonzalez contributed equally to this work)
}

\begin{abstract}
The modulatory action of estradiol $\left(\mathrm{E}_{2}\right)$ on the $\mathrm{GnRH}$ network can be exerted indirectly on presynaptic neurons or directly on estrogen receptors (ERs) located within GnRH hypothalamic neurons. Using the GnRH-producing GT1-7 cell line, we have investigated whether $\mathrm{E}_{2}$ is able to modify the response of these cells to norepinephrine (NE) stimulation. A 48-h exposure of GT1-7 cells to $10 \mathrm{nM} \mathrm{E_{2 }}$ reduced NE-induced cAMP accumulation. However, 15-min exposure was enough to induce this inhibitory action, provided that a hormone-free period of $48 \mathrm{~h}$ after steroid treatment was allowed. Furthermore, this effect was mimicked by $\mathrm{E}_{2}$ coupled to (E-BSA), indicating that it may be exerted through a membrane-mediated mechanism. In addition, competition experiments using E-BSA coupled to fluorescein isothiocyanate (FITC) revealed the presence of cell membrane-binding sites for $\mathrm{E}_{2}$. Binding of E-BSA
\end{abstract}

coupled to FITC was blocked by preincubation of cells with either $\mathrm{E}_{2}$, antiestrogen ICI 182780 , or tamoxifen. Moreover, fluorescence staining of non-permeabilized cells with antibodies against receptors $\alpha$ and $\beta$ confirmed the presence of both receptor subtypes at the cell membrane. To determine the nature of the ER involved in this response, specific agonists for ER $\alpha$ 4,4',4"-(4-propyl- $\left[{ }^{1} \mathrm{H}\right]$ pyrazole-1,3,5triyl)tris-phenol (PPT) and ER $\beta$ 2,3-bis(4-hydroxyphenyl)propionitrile (DPN) were used. Since PPT, but not DPN, reproduced the effect of $E_{2}$, it is suggested that estrogeninduced modulatory action on NE responsiveness was mediated by the ER $\alpha$ isoform. Taken together, these results indicate that $\mathrm{E}_{2}$ modulates the adrenergic sensitivity of GT1-7 cells by a mechanism compatible with the activation of membrane-associated ERs.

Journal of Endocrinology (2007) 194, 193-200

\section{Introduction}

The coordination of episodic release of gonadotrophinreleasing hormone $(\mathrm{GnRH})$ by hypothalamic neurons with GnRH-dependent secretion of pituitary gonadotropins constitutes the central paradigm in the control of mammalian reproduction. The pattern of GnRH secretion is the result of intrinsic oscillatory activity of $\mathrm{GnRH}$ neurons and the integration of presynaptic inputs involving a wide variety of neurotransmitters (Kordon et al. 1994). In females, ovarian hormones act on the GnRH neuronal network to transynaptically modulate the final output of GnRH into the median eminence (Herbison 1998, Herbison \& Pape 2001). Estradiol ( $\left.E_{2}\right)$, the main endogenous regulator of the hypothalamus-pituitary axis, acts through estrogen receptors (ER) at different levels of the above-mentioned system and induces both excitatory and inhibitory effects on GnRH secretion (Fink 2000). In spite of the sustained idea denying the presence of ERs in GnRH neurons, it is now being accepted that these cells express both membrane-associated and nuclear receptors and that they are capable of directly responding to changes in circulating $\mathrm{E}_{2}$ (Malyala et al. 2005).

Due to the scattered distribution of GnRH neurons, the characterization of specific estrogen effects and the identification of estrogen-dependent signaling pathways have been extremely difficult. In this respect, immortalized GnRHproducing GT1-7 cells have constituted a valuable tool to study the biology of GnRH neurons (Nunez et al. 1998, Vazquez-Martinez et al. 2001). By using this experimental model, it has been shown that $\mathrm{E}_{2}$ is able to directly activate G-protein-dependent signaling cascades, to affect the secretory pattern of GnRH (Navarro et al. 2003), and to modulate the response of $\mathrm{GnRH}$-producing cells to classical neurotransmitters (Morales et al. 2003, 2005). We previously found that treatment of GT1-7 cells with $\mathrm{E}_{2}$ for $48 \mathrm{~h}$ inhibited the accumulation of cAMP induced by norepinephrine (NE), and that this effect was apparently exerted at a level upstream adenylyl cyclase (AC; Martinez-Morales et al. 2001). In the present work, we have investigated whether this modulatory effect can be exerted through estrogen interactions with membrane-binding sites. 


\section{Materials and Methods}

\section{Cell culture}

GT1-7 cells (provided by P Mellon, University of California, San Diego, CA, USA) were grown in a Dulbecco's modified Eagle's medium (DMEM), containing 10\% fetal bovine serum (FBS, Sigma-Aldrich), $4.5 \mathrm{~g} / 1$ glucose, $0.58 \mathrm{~g} / 1$ glutamine, $3.7 \mathrm{~g} / 1 \mathrm{NaHCO}_{3}, 100 \mu \mathrm{g} / \mathrm{ml}$ gentamicin, and $50 \mu \mathrm{g} / \mathrm{ml}$ penicillin. The cells were cultured at $37^{\circ} \mathrm{C}$ under $5 \% \mathrm{CO}_{2}-$ 95\% air on $35 \mathrm{~mm}$ plates (Falcon, Becton Dickson, NJ, USA). Before any treatment, cells were washed in PBS, $\mathrm{pH} 7 \cdot 2$, and cultured for $24 \mathrm{~h}$ in serum- and phenol red-free Opti-MEM (Gibco BRL).

\section{Reagents}

The $17 \beta-\mathrm{E}_{2}, 17 \alpha-\mathrm{E}_{2}$, tamoxifen (TX), NE, 3-isobutyl-1methylxanthine (IBMX), BSA, $\mathrm{E}_{2}$ coupled to bovine serum albumin (E-BSA, 17 $\beta-\mathrm{E}_{2}$ 6-(O-carboxy-methyl)oxime:BSA; $35 \mathrm{~mol} \mathrm{E}_{2} / \mathrm{mol} \mathrm{BSA}$ ), and $\mathrm{E}_{2}-\mathrm{BSA}$-fluorescein isothiocyanate (E-BSA-FITC) were obtained from Biosigma (Madrid, Spain). 4, 4', 4" -(4-Propyl- $\left[{ }^{1} \mathrm{H}\right]$ pyrazole-1,3,5-triyl)trisphenol (PPT) and 2,3-bis(4- hydroxyphenyl)-propionitrile (DPN) were obtained from Tocris (Madrid, Spain). ICI 182780 was a gift from Astra-Zeneca (Madrid, Spain). The MC-20 polyclonal anti-ER $\alpha$ antibody, which recognizes amino acid residues 580-599 from mouse ER $\alpha$, was obtained from Santa Cruz Biotechnology (Santa Cruz, CA, USA). The PA1-310B polyclonal anti-ER $\beta$, which recognizes amino acid residues 467-485 from rat ER $\beta$, was obtained from Affinity Bioreagents (Golden, CO, USA). The secondary goat biotinylated anti-rabbit antibody and cyanine-2 dye-conjugated streptavidin were respectively from Vector Laboratories (Burlingame, CA, USA) and Jackson Laboratories (Baltimore, PA, USA). An enzyme immunoassay detection kit for cAMP was obtained from Amersham Biosciences (EIA, RPN225, Little Chalfont, Bucks, UK).

\section{Determination of NE-induced cAMP accumulation}

GT1-7 cells were grown in DMEM on $35 \mathrm{~mm}$ plates until they reached $60-80 \%$ confluence. Then, $24 \mathrm{~h}$ before treatments, media were changed to Opti-MEM. In the first set of experiments, cells were exposed to $10 \mathrm{nM} \mathrm{E}_{2}$ for different times $(15 \mathrm{~min}, 6 \mathrm{~h}$, or $48 \mathrm{~h}$ ) and, at the end of the hormone incubation period, they were treated with $10 \mu \mathrm{M}$ $\mathrm{NE}$ or the vehicle for $15 \mathrm{~min}$. In the second set of experiments, immediately after incubation with $E_{2}$ for the same periods as before, culture medium was replaced by fresh hormone-free medium and incubated for additional periods to reach a total time of $48 \mathrm{~h}(48,42$, or $0 \mathrm{~h})$, and thereafter the cells were treated with either NE or the vehicle for $15 \mathrm{~min}$. Treatments with E-BSA, PPT, or DPN were performed according to the following experimental protocol: cells were exposed to $10 \mathrm{nM}$ E-BSA, $100 \mathrm{nM}$ PPT, or $100 \mathrm{nM}$ DPN for
$15 \mathrm{~min}$, afterwards culture medium was replaced by fresh hormone-free medium and incubated for a total time of $48 \mathrm{~h}$ before the addition of $\mathrm{NE}$ or the vehicle for $15 \mathrm{~min}$. To eliminate potential contamination of E-BSA with unconjugated $\mathrm{E}_{2}, \mathrm{E}-\mathrm{BSA}$ solution was prepared by filtration using a Microcon cartridge with a $10 \mathrm{kDa}$ cutoff (meter microcon YM-10, Millipore, Madrid, Spain), following the protocol described by Stevis et al. (1999).

In all the cases, the cells were preincubated with the phosphodiesterase inhibitor IBMX $(0 \cdot 25 \mathrm{mM})$ for $60 \mathrm{~min}$ before adrenergic stimulation. After treatments, media were discarded, cells were lysed in $200 \mu$ l of $0 \cdot 25 \%$ dodecyltrimethylammonium bromide solution, and frozen at $-80{ }^{\circ} \mathrm{C}$ until assayed. Cyclic AMP content was determined in duplicate by an enzyme immunoassay kit. The detection limit was $12 \mathrm{fmol}$, and the inter- and intra-assay variabilities were $<15 \%$.

\section{E-BSA-FITC binding assay}

Cells cultured on glass coverslips were washed twice with

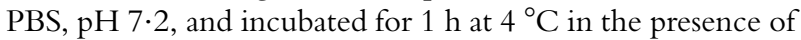
$10 \mu \mathrm{M}$ E-BSA-FITC. For competition assays, prior to the addition of E-BSA-FITC, cultures were exposed to $\mathrm{E}_{2}, 17 \alpha-$ $\mathrm{E}_{2}$, TX, or ICI 182780 (30 and $100 \mu \mathrm{M}$ each) for $1 \mathrm{~h}$ at $37^{\circ} \mathrm{C}$. As a control of unspecific binding, other cells were incubated with $100 \mu \mathrm{M}$ BSA for $1 \mathrm{~h}$ and then exposed to $10 \mu \mathrm{M}$ E-BSA-FITC. Cells were washed twice with PBS and processed for confocal microscopy visualization. The fluorescent light emitted at the cell membrane was monitored by taking emission images. Relative pixel intensities of individual fluorescent cells were quantified by using Fluoview 1000 software (Olympus FV1000, Barcelona, Spain). Local background was subtracted, and identical experimental and parametrical conditions were used for all treatments.

\section{Membrane-localized $E R \alpha$ and $E R \beta$}

Cells cultured on glass coverslips were washed twice with PBS, $\mathrm{pH} 7 \cdot 2$, and fixed under unpermeabilized conditions in PBS containing 2\% PFA, $0.05 \%$ glutaraldehyde, and $120 \mathrm{mM}$ sucrose for $30 \mathrm{~min}$ at room temperature. The non-permeabilizing fixative conditions employed here have previously been reported to preserve plasma membrane integrity and to prevent anti-ER antibodies from passing across the plasma membrane (Clarke et al. 2000). After fixation, cells were washed in PBS and incubated at room temperature with normal goat serum to reduce nonspecific binding. MC-20 and PA1-310B anti-ER antibodies were incubated in PBS for $2 \mathrm{~h}$ at room temperature. The secondary biotinylated anti-rabbit antibody (1:200) was incubated for $1 \mathrm{~h}$ at room temperature, and staining was revealed by incubation with cyanine-2 dye-conjugated streptavidin (1:500) for $30 \mathrm{~min}$ at room temperature. After washing in PBS, cells were mounted in PBS/glycerol (1:1). Negative controls were performed in the absence of primary antibodies. Immunosignals were processed using Fluoview 1000 laser scanning confocal imaging system. 


\section{Statistical analyses}

Data are expressed as mean \pm s.E.M. Significant differences among groups were tested by one-way ANOVA followed by the Tukey's post hoc test. Statistical significance is indicated in the figures from $P<0 \cdot 05$.

\section{Results}

\section{Modulation of NE-induced cAMP accumulation by $E_{2}$}

As previously reported (Martinez-Morales et al. 2001), pretreatment of GT1-7 cells with $\mathrm{E}_{2}(10 \mathrm{nM})$ for $48 \mathrm{~h}$, but for neither $15 \mathrm{~min}$ nor $6 \mathrm{~h}$, reduced NE-induced cAMP accumulation when the neurotransmitter was applied immediately after hormone exposure (Fig. 1A). In the second experiment, cells were pretreated with the same
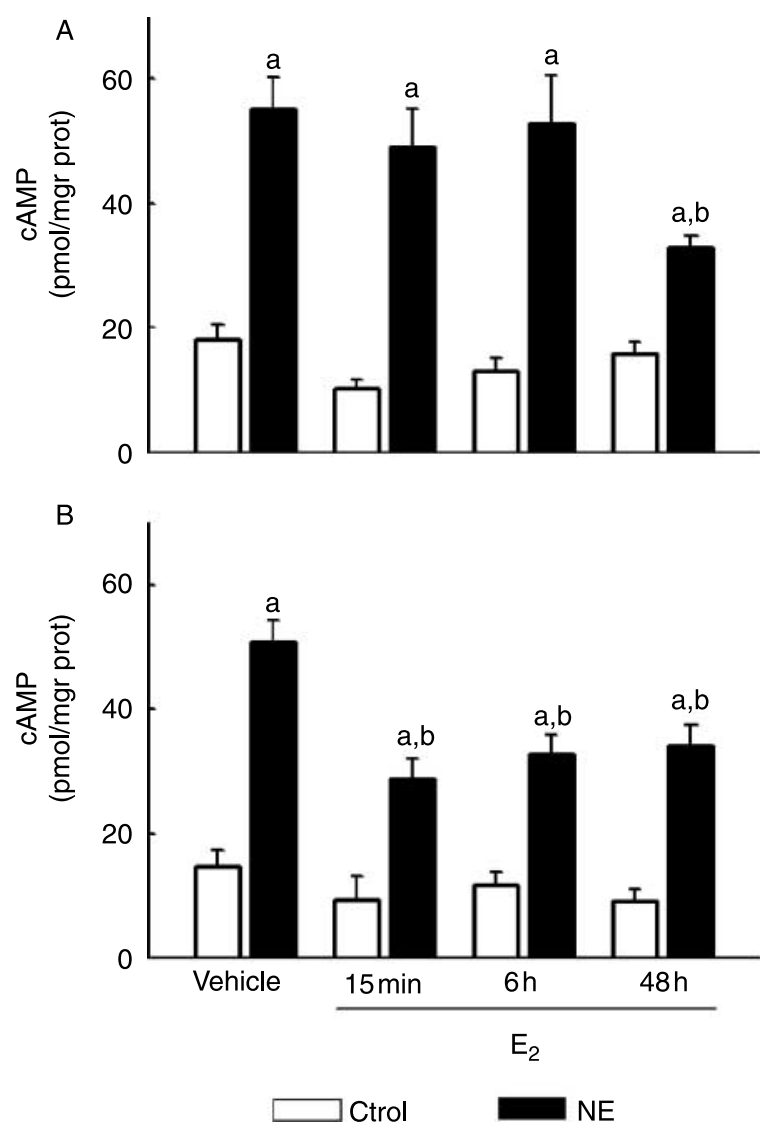

Figure 1 Effect of $17 \beta$-estradiol on NE-induced accumulation of CAMP. (A) Cells were pretreated with $10 \mathrm{nM} \mathrm{E}_{2}$ or the vehicle $(0.001 \%$ ethanol) for $15 \mathrm{~min}, 6 \mathrm{~h}$, or $48 \mathrm{~h}$, and then the cells were treated with norepinephrine $(\mathrm{NE}, 10 \mu \mathrm{M})$ or vehicle (Ctrol) for $15 \mathrm{~min}$. (B) Cells were pretreated with $10 \mathrm{nM} \mathrm{E}_{2}$ or the vehicle $(0.001 \%$ ethanol) for $15 \mathrm{~min}, 6 \mathrm{~h}$, or $48 \mathrm{~h}$, and the cells were stimulated with NE after a total period of $48 \mathrm{~h}$ for each group. Cyclic AMP was determined in duplicate by an enzyme immunoassay kit, and each bar represents the mean \pm S.E.M. of six plates per group. ${ }^{\text {a }} P<0 \cdot 001$ versus Ctrol; ${ }^{b} P<0 \cdot 01$ versus NE in the vehicle group. concentration of $\mathrm{E}_{2}$ for $15 \mathrm{~min}, 6 \mathrm{~h}$, or $48 \mathrm{~h}$ but, in this case, a total period of $48 \mathrm{~h}$ was allowed prior to NE stimulation. Thus, when exposure to $\mathrm{E}_{2}$ was shorter than $48 \mathrm{~h}$ (15 min or $6 \mathrm{~h})$, culture medium was replaced by fresh hormone-free medium. Interestingly, short exposures to the same concentration of $E_{2}$ produced an equivalent inhibition of NE-induced cAMP accumulation when the effect of $E_{2}$ had a total latency of $48 \mathrm{~h}$ (Fig. 1B).

\section{Estrogen modulatory effect is initiated at the plasma membrane}

Even though estrogen effect on NE-induced cAMP accumulation has a long latency, which is compatible with a genomic mechanism, this action could be initiated at the plasma membrane level, as a short exposure to $E_{2}$ is enough to inhibit adrenergic stimulation. To test this hypothesis, we used $17 \beta-E_{2}$ coupled to BSA (E-BSA), a membrane-impermeant analog of $E_{2}$. Cells were pretreated with E-BSA and $E_{2}$ for $15 \mathrm{~min}$ and then, after $48 \mathrm{~h}$ incubation in hormone-free medium, stimulated with NE. As shown in Fig. 2, a similar inhibitory effect of both compounds on NE-induced cAMP accumulation was observed. BSA alone did not show any effect on cAMP levels induced by NE (data not shown), thus demonstrating the specificity of E-BSA action.

Impermeant conjugate E-BSA-FITC binds to specific sites of the plasma membrane

The fact that the membrane-impermeant molecule E-BSA reproduces the effect of $E_{2}$ suggests the presence of estrogen plasma membrane-binding sites in GT1-7 cells. To analyze the existence and specificity of these binding sites, we exposed the cells to E-BSA coupled to FITC. After incubation with

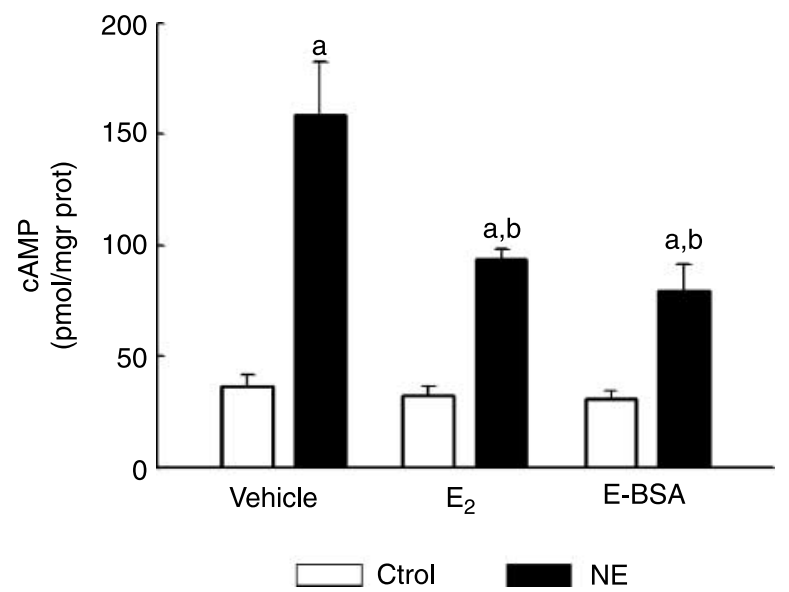

Figure 2 Effect of $17 \beta$-estradiol and E-BSA on NE-induced accumulation of cAMP. Cells were pretreated with $10 \mathrm{nM} \mathrm{E}_{2}$, $10 \mathrm{nM}$ E-BSA, or the vehicle $(0 \cdot 001 \%$ ethanol $)$ for $15 \mathrm{~min}$, and after $48 \mathrm{~h}$, they were stimulated with $10 \mu \mathrm{M} \mathrm{NE}$ or the vehicle (Ctrol) for $15 \mathrm{~min}$. Cyclic AMP was determined in duplicate by an enzyme immunoassay kit, and each bar represents the mean \pm S.E.M. of six plates per group. ${ }^{\mathrm{a}} P<0 \cdot 001$ versus $\mathrm{Ctrol}$; ${ }^{\mathrm{b}} \mathrm{P}<0.01$ versus NE in the vehicle group. 
this compound, $\approx 90 \%$ of the cells exhibited fluorescent labeling at the cell membrane, which was unaffected by preincubation with an excess $(100 \mu \mathrm{M})$ of BSA (Fig. 3A and B). The binding of E-BSA-FITC was partially blocked by a threefold excess of either $\mathrm{E}_{2}$ (Fig. 3C), antiestrogen ICI 182780 (Fig. 3E), or selective ER modulator TX (Fig. 3G). A nearly complete blockade of immunostaining at the outer cell membrane was obtained by preincubation of cells with $100 \mu \mathrm{M} \mathrm{E}_{2}$, ICI 182780 , or TX (Fig. 3D, F, and $\mathrm{H}$ respectively). However, $100 \mu \mathrm{M}$ of the relatively inactive stereoisomer $17 \alpha-\mathrm{E}_{2}$ did not modify the binding of E-BSAFITC to the plasma membrane (Fig. 3J), thereby suggesting that these binding sites present in GT1-7 cells are specific for $\mathrm{E}_{2}$. Quantification of the percentage of labeled spots revealed a dose-dependent reduction in the binding of E-BSA-FITC at the cell membrane with increasing concentrations of either $\mathrm{E}_{2}$, ICI 182780 , or TX (Fig. 3I).

\section{Immunoreactivity for $E R \alpha$ and $E R \beta$ at the plasma membrane domain}

Since estrogen seems to bind to specific receptors at the plasma membrane of GT1-7 cells, we further explored the putative structural homologies of $\operatorname{ER} \alpha$ and $\operatorname{ER} \beta$ with these membrane-related $E_{2}$-binding molecules. Non-permeabilized GT1-7 cells were incubated with either MC-20 or PA1310B antibody directed to the carboxy-terminal region of $\operatorname{ER} \alpha$ and $\operatorname{ER} \beta$ respectively. The visualization of cells by confocal microscopy revealed fluorescence staining for both $\mathrm{ER} \alpha$ (Fig. 4A and B) and ER $\beta$ (Fig. 4C and D). These results suggest that binding sites for $\mathrm{E}_{2}$ at the plasma membrane of GT1-7 cells share structural homologies with classical ERs, $\mathrm{ER} \alpha$ and $\mathrm{ER} \beta$, at least at their carboxy-terminal domain.

\section{Specific activation of $E R \alpha$ mimicked the effect of $E_{2}$}

Since the plasma membrane of GT1-7 cells exhibits binding sites for $\mathrm{E}_{2}$ sharing structural homologies with both classical ERs, we sought to determine the potential role of ER subtypes in mediating the modulation of $\mathrm{E}_{2}$ on NE-induced cAMP accumulation by using the selective $\operatorname{ER} \alpha$ and $E R \beta$ agonists, PPT and DPN respectively. Cells were pretreated with $E_{2}$, PPT, or DPN for 15 min and then, after $48 \mathrm{~h}$ incubation in hormone-free medium, stimulated with NE. As shown in Fig. 5, $100 \mathrm{nM}$ PPT, but not DPN, produced a complete inhibition of cAMP accumulation induced by adrenergic stimulation. This total blockade can be explained by the high concentration of PPT that we have used in our assay $(100 \mathrm{nM})$, because this specific agonist has a median effective concentration $\mathrm{EC}_{50}$ of ca. $1 \mathrm{nM}$ on ER $\alpha$ (Stauffer et al. 2000). These results indicate that the effect of $E_{2}$ is mediated by the activation of the ER $\alpha$ subtype.

\section{Discussion}

We have previously reported that the accumulation of cAMP induced by NE in GT1-7 cells is reduced by $48 \mathrm{~h}$ preexposure to nanomolar concentrations of $\mathrm{E}_{2}$ (MartinezMorales et al. 2001). Since $\mathrm{E}_{2}$ did not affect the accumulation of cAMP induced by forskolin, a direct activator of AC, it was suggested that the final target of estrogen action was located upstream the enzyme responsible for second messenger production. Moreover, the temporal pattern of hormone treatment was compatible with a genomic mechanism and a classical ER was thought to be involved. However, in the present study, we show that short exposures to $E_{2}(15 \mathrm{~min})$ are sufficient to reduce NE-induced cAMP accumulation in GT1-7 cells, provided that a $48-\mathrm{h}$ period is allowed prior to adrenergic stimulation. Furthermore, estrogen exerts its modulatory effect through a mechanism that is initiated at the plasma membrane, since the effect of $\mathrm{E}_{2}$ is reproduced by equivalent doses of E-BSA, a compound that is unable to cross the plasma membrane (Caldwell \& Moe 1999, Stevis et al. 1999). We have also found that GT1-7 cells exhibit membrane-binding sites that are specific for $\mathrm{E}_{2}$, which are blocked by related compounds in a concentration-dependent manner. In addition, in non-permeabilized cells, confocal microscopy revealed fluorescence staining for both ER $\alpha$ and ER $\beta$ when using antibodies against their carboxy-terminal domain. Even though both isoforms of ER are detected at the plasma membrane, our results indicate that $\mathrm{E}_{2}$ modulates the response of GT1-7 cells to adrenergic stimulation through selective activation of $\mathrm{ER} \alpha$, since PPT, but not DPN, reproduced the effect of $\mathrm{E}_{2}$ on NE-induced cAMP accumulation. Taken together, these results indicate that, at nanomolar concentrations, $\mathrm{E}_{2}$ is able to modulate noradrenergic responsiveness in GnRH-producing GT1-7 cells by a mechanism compatible with hormone interactions with membrane-associated ER $\alpha$.

Rapid effects of $E_{2}$ noticeable within seconds or minutes have been extensively reported (Nadal et al. 2001). Depending on the cell type, estrogen exposure elicits rapid activation of different signaling pathways and second messenger-dependent kinases through the binding of estrogen to the plasma membrane (Pedram et al. 2002, Zhang et al. 2002, Guerra et al. 2004). Moreover, changes in transcription from ERE-containing genes or genes lacking ERE promoters can be led by membrane-initiated hormone actions (reviewed in Vasudevan \& Pfaff 2007). Since estrogen-responding cells may contain both membrane-associated and classical nuclear ERs, it is conceivable that different signaling cascades may be integrated to promote the final cell response (Levin 2005, Marin et al. 2005).

With respect to the nature of membrane-associated receptors, several studies have reported that they may be the same molecules rather than their intracellular counterparts, derived from the same transcripts other than ER $\alpha$ and ER $\beta$ (Razandi et al. 1999), and responsible for rapid signaling in 

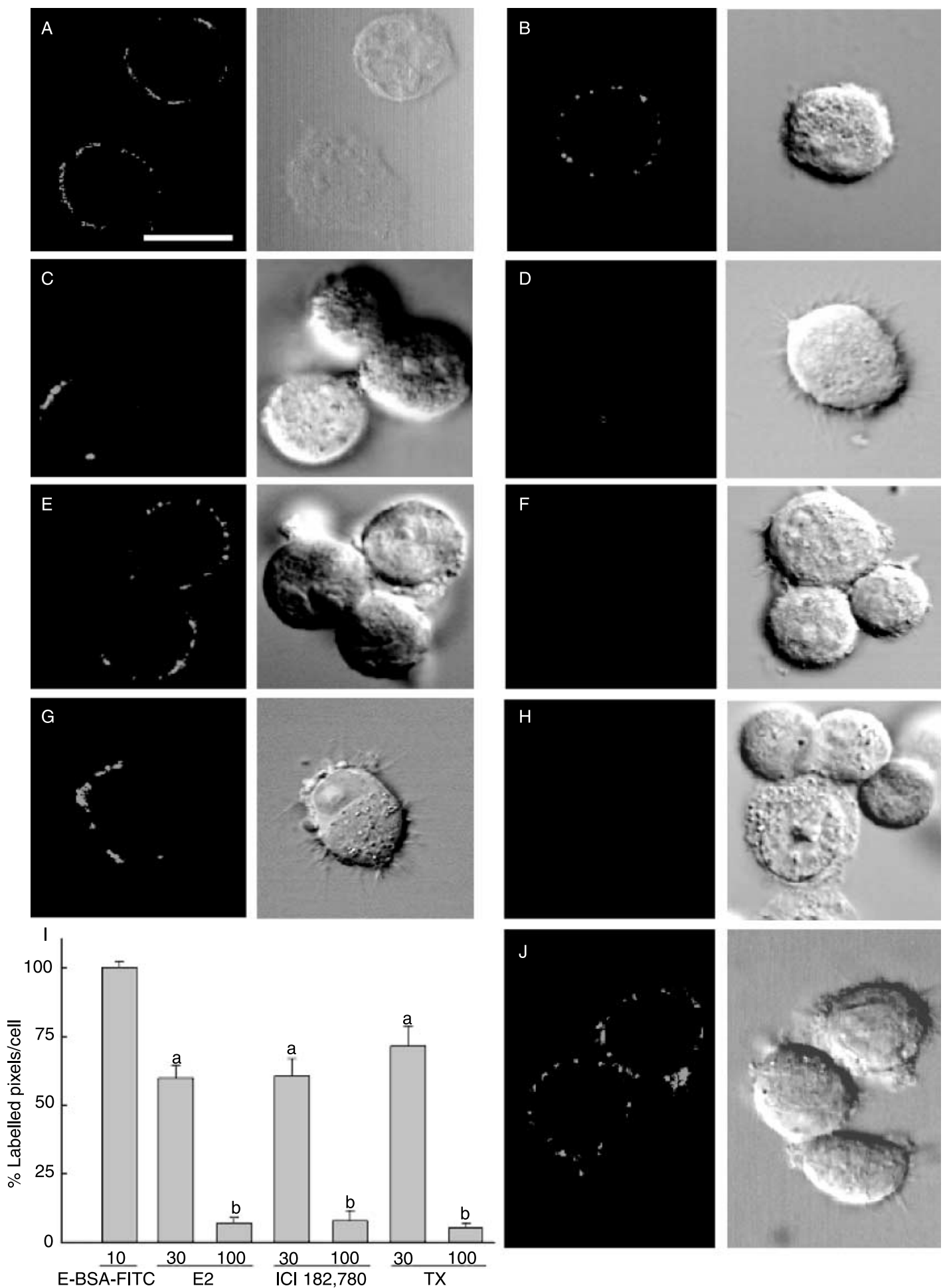

Figure 3 E-BSA-FITC binding of GT1-7 cells and competition with $\mathrm{E}_{2}$, ICI 182 780, tamoxifen (TX), and 17 $\alpha$-estradiol. Specific fluorescence staining was detected at the membrane of cells with $10 \mu \mathrm{M}$ E-BSA-FITC (A). This labeling remained unaffected with a tenfold excess of BSA (B) and partially competed off with $30 \mu \mathrm{ME}_{2}(\mathrm{C}), \mathrm{ICl} 182780(\mathrm{E})$, or TX (G). Doses of $100 \mu \mathrm{M}$ of the same compounds completely blocked the staining of EBSA-FITC (D, F, and $\mathrm{H}$ respectively), whereas $100 \mu \mathrm{M} 17 \alpha$-estradiol did not affect the labeling (J). (I) Quantification of labeled pixels in cells exposed to E-BSA-FITC and $\mathrm{E}_{2}, \mathrm{ICl} 182780$, or TX for the different doses used. Values are referred to the percentage of pixel intensities in E-BSAFITC cells used as a control. ${ }^{a} P<0.05$ and ${ }^{b} P<0 \cdot 001$ versus E-BSA-FITC. Number of analyzed cells per group is 25 . Scale bar $=10 \mu \mathrm{m}$. 

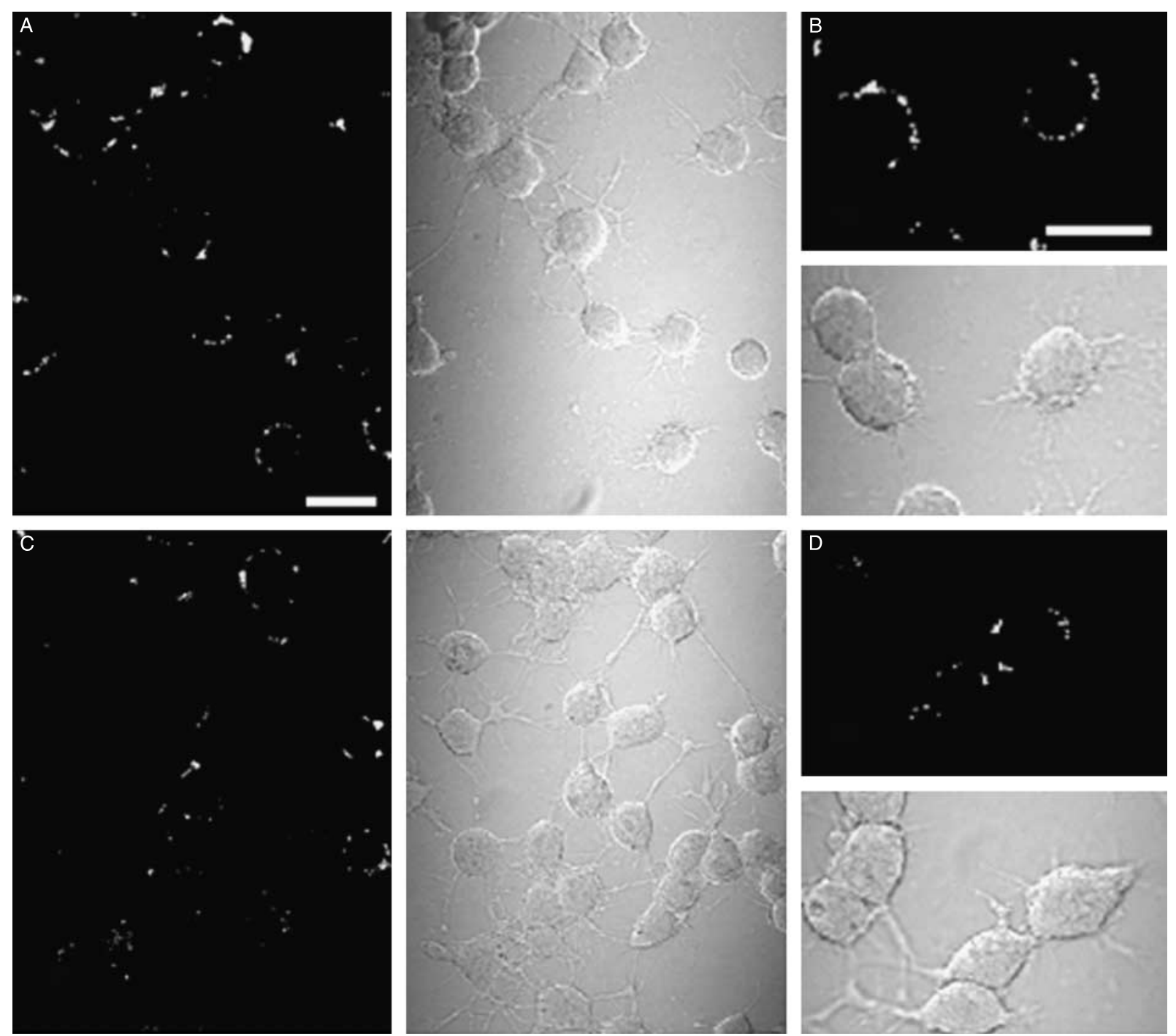

Figure 4 Membrane localization of ER $\alpha$ and ER $\beta$ in GT1-7 cells. Cells were fixed under non-permeabilizing conditions and incubated with the anti-ER $\alpha$ antibody MC-20 (A and B) and the anti-ER $\beta$ PA1-310B (C and D). Scale bar $=10 \mu \mathrm{m}$.

different cell types (Razandi et al. 2003, 2004, Marin et al. 2006). On the contrary, other investigations have revealed membrane-mediated actions of $\mathrm{E}_{2}$ exerted through the activation of proteins other than classical ER. In line with this possibility, some fragmentary evidence points to the existence of a G-protein-coupled receptor (GPR30), which is able to bind estrogen and activate intracellular signaling pathways (Filardo et al. 2002, Revankar et al. 2005, Thomas et al. 2005). Thus, it remains to be determined whether the vast majority of rapid estrogen effects are only dependent on classical ERs associated with the plasma membrane or, alternatively, that other estrogen-binding proteins may contribute to overall cell responses (Pedram et al. 2006).

The presence of ERs in hypothalamic GnRH neurons has been a controversial issue for a long time (Herbison 1998, Herbison \& Pape 2001). However, this view changed completely when a second subtype of ER, namely ER $\beta$, was found (Kuiper et al. 1996). It has been shown that certain populations of murine GnRH neurons express both the mRNA encoding ER $\beta$ (Skynner et al. 1999, Hrabovszky et al. 2000, Sharifi et al. 2002) and the protein (Hrabovszky et al. 2001, Kallo et al. 2001, Legan \& Tsai 2003). On the other hand, immortalized GnRH-producing GT1-7 cells express both ER $\alpha$ and ER $\beta$ transcripts and proteins (Butler et al. 1999, Roy et al. 1999, Martinez-Morales et al. 2001), and exhibit plasma membrane estrogen-binding sites (Morales et al. 2003). In the present study, the fact that E-BSA mimics the effect of $\mathrm{E}_{2}$ on NE-induced cAMP accumulation suggests the involvement of membrane-associated ERs. In addition, using E-BSA conjugated to FITC, we have shown the existence of specific estrogen-binding sites at the plasma membrane which are competed, in a dose-dependent 


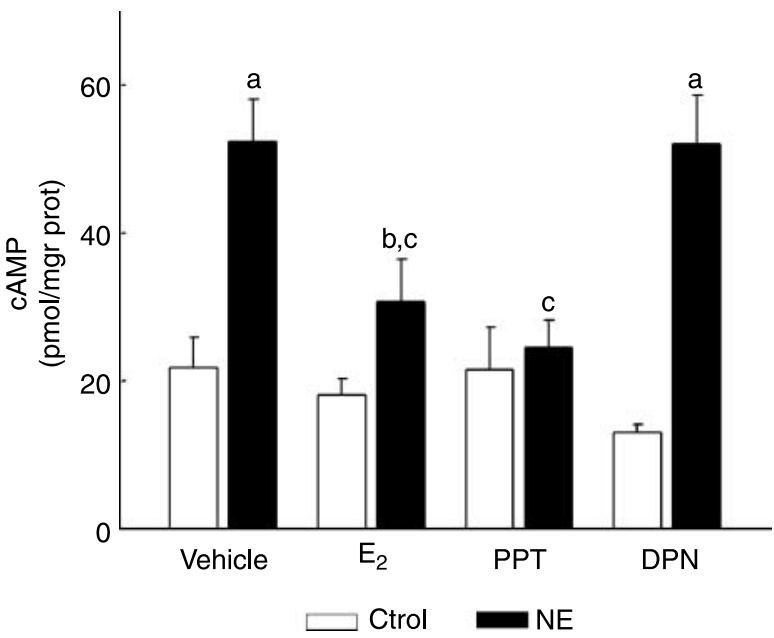

Figure 5 Effect of $17 \beta$-estradiol, PPT, and DPN on NE-induced accumulation of cAMP. Cells were pretreated with $10 \mathrm{nM} \mathrm{E}_{2}$, $100 \mathrm{nM}$ PPT, $100 \mathrm{nM}$ DPN, or the vehicle $(0 \cdot 001 \%$ ethanol) for $15 \mathrm{~min}$, and after $48 \mathrm{~h}$, they were exposed to $10 \mu \mathrm{M} \mathrm{NE}$ or the vehicle (Ctrol) for $15 \mathrm{~min}$. Cyclic AMP was determined in duplicate by an enzyme immunoassay kit, and each bar represents the mean \pm S.E.M. of six plates per group. ${ }^{a} P<0.001$ versus Ctrol; ${ }^{\mathrm{b}} P<0.05$ versus $\mathrm{Ctrol} ;{ }^{\mathrm{c}} P<0.01$ versus $\mathrm{NE}$ in the vehicle group.

manner, by either $\mathrm{E}_{2}$, ICI 182780 , or TX. Although $\mathrm{E}_{2}$ coupled to BSA has been widely used to mimic a membranelimited action for $\mathrm{E}_{2}$, there has been some controversy over the possible release of free $\mathrm{E}_{2}$ from the conjugate and the possibility of endocytosis of the conjugate itself. In our study, before the application to the cells, E-BSA solution was filtered to remove potential free $\mathrm{E}_{2}$. Furthermore, we can rule out the endocytosis of E-BSA since the incubation of GT1-7 cells with E-BSA-FITC for $1 \mathrm{~h}$, at either 37 or $4{ }^{\circ} \mathrm{C}$, did not provoke the entrance of the conjugate into the cells (Morales et al. 2003).

Fluorescence staining of non-permeabilized GT1-7 cells with antibodies against the ligand-binding domain of ER $\alpha$ and $\operatorname{ER} \beta$ has confirmed the presence of these isoforms as previously described by other groups (Navarro et al. 2003). The modulatory action of PPT, a highly selective and specific ER $\alpha$ agonist, on the NE-induced cAMP accumulation led us to conclude that the effect of $E_{2}$ on adrenergic responsiveness in GT1-7 cells is exerted through the interaction with membrane-associated ER $\alpha$.

A number of $E R \alpha$ isoforms have been involved in rapid and alternative estrogen signaling. Flouriot and colleagues have identified a $46 \mathrm{kDa}$ isoform that lacks exon 1 and, consequently, the N-terminal AF-1 region (Flouriot et al. 2000). This isoform has been identified at the plasma membrane of several cell types, where it modulates membrane-initiated estrogen actions ( $\mathrm{Li}$ et al. 2003). Recently, a new spliced variant of ER $\alpha$, hER- $\alpha 36$, has been identified (Wang et al. 2006). This protein lacks the two transcriptional activation domains, and it is predominantly associated with the plasma membrane.
In mammals, the pattern of GnRH secretion is under the control of estrogen acting at different levels of the hypothalamic neuronal network (Herbison 1998). Studies from immortalized GT1-7 cells have helped clarify some of the mechanisms that may participate in direct estrogen modulation of GnRH neuronal activity. Estrogen has been shown to exert both inhibitory and stimulatory, dose-dependent effects on GnRH pulsatile secretion and cAMP formation (Navarro et al. 2003). In addition, $E_{2}$ also modulates acetylcholine-induced calcium signals by a membrane-mediated mechanism involving cGMP formation and PKG-dependent inositol triphosphate receptor phosphorylation (Morales et al. 2003, 2005). We now report for the first time that estrogen modulation of noradrenergic responsiveness is initiated at the plasma membrane of GT1-7 cells. Since GnRH neurons are the target of multiple presynaptic inputs, estrogen-dependent modulation of neurotransmitter sensitivity can be an efficient way to adapt the response of this neuronal system to gonadal steroids during mammalian ovarian cycles.

\section{Acknowledgements}

This work was supported by grants SAF-2004-08316-C0201, PI84/04, and PI042640. A M and R M are fellows of the 'Juan de la Cierva' and 'Ramon y Cajal' Programmes from the Spanish MEC respectively. The authors declare that there is no conflict of interest that would prejudice the impartiality of this scientific work.

\section{References}

Butler JA, Sjöberg M \& Coen CW 1999 Evidence for oestrogen receptor $\alpha$-immunoreactivity in gonadotrophin-releasing hormone-expressing neurones. Journal of Neuroendocrinology 11 331-335.

Caldwell JD \& Moe BD 1999 Conjugated estradiol increases female sexual receptivity in response to oxytocin infused into the medial preoptic area and medial basal hypothalamus. Hormones and Behavior 35 38-46.

Clarke CH, Norfleet AM, Clarke MS, Watson CS, Cunningham KA \& Thomas ML 2000 Perimembrane localization of the estrogen receptor $\alpha$ protein in neuronal processes of cultured hippocampal neurons. Neuroendocrinology 71 34-42.

Filardo EJ, Quinn JA, Frackelton R \& Bland KI 2002 Estrogen action via the G protein-coupled receptor, GPR30: stimulation of adenylyl cyclase and cAMP-mediated attenuation of the epidermal growth factor receptorto-MAPK signaling axis. Molecular Endocrinology 16 70-84.

Fink G 2000 Neuroendocrine regulation of pituitary function: general principles. In Neuroendocrinology in Physiology and Medicine, pp 107-134. Eds PM Conn \& ME Freeman. New Jersey: Humana Press.

Flouriot G, Brand H, Denger S, Metivier R, Kos M, Reid G, Sonntag-Buck V \& Gannon F 2000 Identification of a new isoform of the human estrogen receptor-alpha $(\mathrm{hER}-\alpha)$ that is encoded by distinct transcripts and that able to repress hER- $\alpha$ activation function 1. EMBO Journal 19 4688-4700.

Guerra B, Diaz M, Alonso R \& Marin R 2004 Plasma membrane oestrogen receptor mediates neuroprotection against $\beta$-amyloid toxicity through activation of Raf-1/MEK/ERK cascade in septal-derived cholinergic SN56 cells. Journal of Neurochemistry 91 99-109.

Herbison AE 1998 Multimodal influence of estrogen upon gonadotropinreleasing hormone neurons. Endocrine Reviews 19 302-330. 
Herbison AE \& Pape J-R 2001 New evidence for estrogen receptors in gonadotropin-releasing hormone neurons. Frontiers in Neuroendocrinology 22 292-308.

Hrabovszky E, Shughrue PJ, Merchenthaler I, Hajszán T, Carpenter CD, Liposits Z \& Petersen SL 2000 Detection of estrogen receptor- $\beta$ messenger ribonucleic acid and ${ }^{125}$ I-estrogen binding sites in luteinizing hormonereleasing hormone neurons of the rat brain. Endocrinology 141 3506-3509.

Hrabovszky E, Steinhauser AM, Barabás K, Shughrue PJ, Petersen SL, Merchenthaler I \& Liposits Z 2001 Estrogen receptor- $\beta$ immunoreactivity in luteinizing hormone-releasing hormone neurons of the rat brain. Endocrinology 142 3261-3264.

Kallo I, Butler JA, Barkovics-Kallo M, Goubillon ML \& Coen CW 2001 Oestrogen receptor beta-immunoreactivity in gonadotropin releasing hormone-expressing neurones: regulation by oestrogen. Journal of Neuroendocrinology 13 741-748.

Kordon C, Drouva SV, Martinez de la Escalera G, Wiener R et al. 1994 Role of classic and peptide neuromediators in the neuroendocrine regulation of luteinizing hormone and prolactin. In The Physiology of Reproduction, vol 1, pp 1621-1681. Eds E Knobil \& JD Neill. New York: Raven Press.

Kuiper GGJM, Enmark E, Pelto-Huikko M, Nilsson S \& Gustafsson J-A 1996 Cloning of a novel estrogen receptor expressed in rat prostate and ovary. PNAS 93 5925-5930.

Legan SJ \& Tsai HW 2003 Oestrogen receptor-alpha and beta immunoreactivity in gonadotropin-releasing hormone neurons after ovariectomy and chronic exposure to oestradiol. Journal of Neuroendocrinology 15 $1164-1170$

Levin ER 2005 Integration of the extra-nuclear and nuclear actions of estrogen. Molecular Endocrinology 19 1951-1959.

Malyala A, Kelly MJ \& Rønnekleiv OK 2005 Estrogen modulation of hypothalamic neurons: activation of multiple signaling pathways and gene expression changes. Steroids 70 397-406.

Marin R, Guerra B, Alonso R, Ramirez C \& Diaz M 2005 Estrogen activates classical and alternative mechanisms to orchestrate neuroprotection. Current Neurovascular Research 2 287-301.

Marin R, Ramirez CM, Gonzalez M, Alonso R \& Diaz M 2006 Alternative estrogen receptors homologous to classical receptor $\alpha$ in murine neural tissues. Neuroscience Letters 395 7-11.

Martinez-Morales JR, Morales A, Marin R, Hernandez-Jimenez JG, Acevedo A, Guerra B, Hernandez G, Lopez-Coviella I, Prieto L \& Alonso R 2001 Estrogen modulates norepinephrine-induced accumulation of cyclic monophosphate in a subpopulation of immortalized luteinizing hormonereleasing hormone secreting neurons from the mouse hypothalamus. Neuroscience Letters 298 61-64.

Morales A, Diaz M, Ropero AB, Nadal A \& Alonso R 2003 Estradiol modulates acetylcholine-induced $\mathrm{Ca}^{2+}$ signals in LHRH-releasing GT1-7 cells through a membrane binding site. European Journal of Neuroscience 18 2505-2514.

Morales A, Diaz M, Guelmes P, Marin R \& Alonso R 2005 Rapid modulatory action of estradiol on acetylcholine-induced $\mathrm{Ca}^{2+}$ signals is mediated by PKG-dependent phosporylation of inositol 1,4,5-triphosphate receptor in LHRH releasing GT1-7 cells. European Journal of Neuroscience 22 2207-2215

Nadal A, Diaz M \& Valverde MA 2001 The estrogen trinity: membrane, cytosolic, and nuclear effects. News in Physiological Sciences 16 251-255.

Navarro CE, Saeed SA, Murdock C, Martinez-Fuentes AJ, Arora KK, Krsmanovic LZ \& Catt KJ 2003 Regulation of cyclic adenosine 3',5'monophosphate signaling and pulsatile neurosecretion by Gi-coupled plasma membrane estrogen receptors in immortalized gonadotrophinreleasing hormone neurons. Endocrinology 17 1792-1804.

Nunez L, Faught WJ \& Frawley LS 1998 Episodic gonadotropin-releasing hormone gene expression revealed by dynamic monitoring of luciferase reporter activity in single, living neurons. PNAS 95 9648-9653.
Pedram A, Razandi M, Aitkenhead M, Hughes CCW \& Levin ER 2002 Integration of the non-genomic and genomic actions of estrogen. Membrane-initiated signaling by steroid to transcription and cell biology. Journal of Biological Chemistry 27 50768-50775.

Pedram A, Razandi M \& Levin ER 2006 Nature of functional estrogen receptors at the plasma membrane. Molecular Endocrinology 20 1996-2009.

Razandi M, Pedram A, Green GL \& Levin ER 1999 Cell membrane and nuclear estrogen receptors (ERs) originate from a single transcript: studies of ERalpha and ERbeta expressed in Chinese hamster ovary cells. Molecular Endocrinology 13 307-319.

Razandi M, Pedram A, Park ST \& Levin ER 2003 Proximal events in signalling by plasma membrane estrogen receptors. Journal of Biological Chemistry 278 2701-2712.

Razandi M, Pedram A, Merchenthaler I, Green GL \& Levin ER 2004 Plasma membrane estrogen receptors exist and function as dimmers. Molecular Endocrinology 18 2854-2865.

Revankar CM, Cimino DF, Sklar LA, Arterblum JB \& Prossnitz ER 2005 A transmembrane intracellular estrogen receptor mediates rapid cell signaling. Science 307 1625-1630.

Roy D, Angelini NL \& Belsham DD 1999 Estrogen directly represses gonadotropin-releasing hormone $(\mathrm{G} n R H)$ gene expression in estrogen receptor- $\alpha(E R \alpha)$ - and ER $\beta$-expressing GT1-7 GnRH neurons. Endocrinology 140 5045-5053.

Sharifi N, Reuss AE \& Wray S 2002 Prenatal LHRH neurons in nasal explant cultures express estrogen receptor beta transcript. Endocrinology 143 2503-2507.

Skynner MJ, Sim JA \& Herbison AE 1999 Detection of estrogen receptor $\alpha$ and $\beta$ messenger ribonucleic acid in adult gonadotropin-releasing hormone neurons. Endocrinology 140 5195-5201.

Stauffer SR, Coletta CJ, Tedesco R, Nishiguchi G, Carlson K, Sun J, Katzenellenbogen BS \& Katzenellenbogen JA 2000 Pyrazole ligands: structure-affinity/activity relationships and estrogen receptor-alpha-selective agonists. Journal of Medicinal Chemistry 43 4934-4947.

Stevis PE, Deecher DC, Suhadolnik L, Mallis LM \& Frail DE 1999 Differential effects of estradiol and estradiol-BSA conjugates. Endocrinology $1405455-5458$

Thomas P, Pang Y, Filardo EJ \& Dong J 2005 Identity of an estrogen membrane receptor coupled to a $G$ protein in human breast cancer cells. Endocrinology 146 624-632.

Vasudevan N \& Pfaff DW 2007 Membrane-initiated actions of estrogens in neuroendocrinology: emerging principles. Endocrine Reviews 28 1-19.

Vazquez-Martinez R, Shorte SL, Faught WJ, Leaumont DC, Frawley LS \& Boockfor FR 2001 Pulsatile exocytosis is functionally associated with $\mathrm{GnRH}$ gene expression in immortalized GnRH-expressing cells. Endocrinology $1425364-5370$

Wang ZY, Zhang XT, Shen P, Loggie BW, Chang Y \& Deuel TF 2006 A variant of estrogen receptor- $\alpha, \mathrm{hER}-\alpha 36$ : transduction of estrogen- and antiestrogen-dependent membrane-initiated mitogenic signaling. PNAS 103 9063-9068.

Zhang Z, Maier B, Santen RJ \& Song RD 2002 Membrane association of estrogen receptor alpha mediates estrogen effect on MAPK activation. Biochemical and Biophysical Research Communications 294 926-933.

Received in final form 10 April 2007

Accepted 18 April 2007

Made available online as an Accepted Preprint 18 April 2007 